\title{
HERMENÊUTICA E[M] RESPOSTA AO ELOGIO DA VERDADEIRA FILOSOFIA DA CARTA SÉTIMA DE PLATÃO
}

\author{
Luiz Rohden* \\ rohden@unisinos.br
}

\begin{abstract}
[...] de modo que a confrontação do pensamento moderno com o pensamento grego é para todos nós uma espécie de encontro conosco mesmos. ${ }^{1}$

[...] dai, ter sido levado a fazer o elogio da verdadeira filosofia, com proclamar que é por meio dela que se pode reconhecer as diferentes formas da justiça politica ou individual. $^{2}$
\end{abstract}

RESUMO Nossa leitura da Carta Sétima parte do pressuposto segundo o qual o filosofar instaura-se sobre um exercício dialético incessante entre fenomenologia e hermenêutica do real. Objetivamos aqui, por um lado, justificar a atualidade e a pertinência da hermenêutica filosófica bem como sua apropriada aplicação aos textos filosóficos e, por outro, elucidar o que julgamos ser o cerne da carta em questão, ou seja, indicar traços fundamentais da verdadeira filosofia e, portanto, dos verdadeiros filósofos segundo nossa leitura do escrito de Platão. Nossa reflexão, em seu conjunto, pretende configurar uma espécie de resposta à carta de Platão, apontando, assim,

* Professor do Departamento de Filosofia da Unisinos. Pesquisador do CNPq. Artigo recebido em 22/08/2011 e aprovado em 26/12/2011.

1 GADAMER, H-G. "La filosofia griega y el pensamiento moderno". In: El início de la sabiduría. Barcelona: Paidós, 2001. p. 126.

2 PLATÃO. "Carta Sétima". In: Fedro - Cartas - O primeiro Alcibíades. Trad. Carlos Alberto Nunes. Pará: Universidade Federal do Pará, 1975. p. 139, 326 a. Utilizaremos essa tradução aqui; no correr do nosso texto, indicaremos as citações da referida obra entre parênteses.

KRITERION, Belo Horizonte, nº 127, Jun./2013, p. 25-42 
nossa posição sobre o exercício filosófico atual. Articularemos nosso propósito sobre dois momentos interconectados entre si: iniciaremos elucidando alguns pressupostos hermenêuticos de leitura do texto platônico com o escopo de explicitar nossos elogios à verdadeira filosofia.

Palavras-chave Platão, Carta Sétima, dialética, Gadamer, Hermenêutica.

ABSTRACT Our reading of the Seventh Letter starts from the assumption that philosophizing is based on an unceasing dialectical exercise that moves between phenomenology and hermeneutics of the real. Our goal here is, on the one hand, to justify the relevance and pertinence of philosophical hermeneutics and its appropriate application to philosophical texts and, on the other hand, to point out what we see as the core of that letter, viz. sketching the basic features of true philosophy and thus of true philosophers according to our reading of Plato's writing. As a whole, our reflection intends to be a kind of response to Plato's letter as it presents our position about the present exercise of philosophy. This is done through two interconnected moments: we begin by discussing some hermeneutical assumptions of the reading of Plato's text, then we express our praise of true philosophy.

Keywords Plato, Seventh Letter, dialectics, Gadamer, hermeneutics.

O projeto filosófico de Platão, aliado à sua leitura da realidade de então, levou-o a fazer o elogio da verdadeira filosofia, com proclamar que é por meio dela que se pode reconhecer as diferentes formas da justiça politica ou individual para quem não cessarão os males para o gênero humano antes de alcançar o poder a raça dos verdadeiros e autênticos filósofos ou de começarem a seriamente filosofar, por algum favor divino, os dirigentes das cidades [326 a] [grifos nossos].

Sabemos que em qualquer projeto de transformação da realidade [pessoal, política, ambiental, etc.] com vistas ao que é melhor implica, inicialmente, numa leitura o mais universal e completa possível sobre ela. Dito de outro modo, uma leitura mal feita do real implica numa palavra mal-dita sobre ele; uma leitura distorcida desemboca numa ação desastrosa, de modo que uma fenomenologia parcial provoca uma hermenêutica da mesma proporção. No aforismo de Heráclito, encontramos respaldada essa hipótese: "não sabendo 
auscultar, não sabem falar", ${ }^{3}$ ou seja, apenas quando auscultamos o real é possível, então, emitir uma palavra o mais possível apropriada sobre e para ele.

Com o pressuposto acima justificamos o filosofar enquanto um exercício dialético infindável entre fenomenologia e hermenêutica à luz da Carta Sétima de Platão, ${ }^{4}$ concedendo certa ênfase ao primeiro polo; nessa reflexão nos ocupamos em desvelar as marcas [os traços] daqueles que não filosofam realmente e apenas aparentam ser filósofos, corporificadas na postura de Dionísio [I e II]. Aqui, à luz de um olhar hermenêutico, nos propusemos ler a carta novamente para refletir, tematizar e justificar nossos elogios ao elogio da verdadeira filosofia nela abordados. Dito de outro modo, desenvolveremos que o filosofar se constitui também pela dimensão propositiva, projetiva e, por que não dizer, ideal-teórica. Nesse caso, trata-se de desvelar aquilo que ela é ou deve ser, e que encontramos corporificado nas declarações e na postura de Platão relativas à 'verdadeira filosofia' e aos 'verdadeiros filósofos'. Enquanto lá concedemos primazia ao olhar de Dionísio em relação à filosofia, aqui olharemos e explicitaremos o olhar hermenêutico de Platão acerca do projeto filosófico ideal.

Eis, pois, porque nos debruçaremos sobre os traços e objetivos daqueles que possuem o pendor filosófico proposto por Platão, dos que realmente filosofam, isto é, dos seus elogios à verdadeira filosofia, aos verdadeiros filósofos. Nosso foco, aqui, não é mostrar quem não é filósofo - como fizemos no texto citado - mas explicitar e aprofundar traços daqueles que se atém ao "saber desinteressado" conforme linguagem de Aristóteles: "de modo que, se os homens filosofaram para libertar-se da ignorância, é evidente que buscavam o conhecimento unicamente em vista do saber e não por alguma utilidade prática". ${ }^{5}$

Tanto o precedente quanto o presente texto possuem pretensões similares, isto é, justificar o modo de filosofar de Platão em nossos dias. Nossos textos configuram uma espécie de resposta à carta em questão, dando mostras bastante claras da nossa posição sobre o filosofar atual. Isso significa que, embora a presente reflexão possua certa autonomia, ela se compreende mais plenamente no horizonte de nossas investigações sobre a filosofia de Platão segundo a ótica da hermenêutica filosófica de Gadamer.

3 HERÁCLITO. Aforismo 19. In: Fragmentos. Rio de Janeiro: Edições de Tempo Brasileiro, 1980. p. 57.

4 Este texto situa-se no conjunto das minhas pesquisas sobre Gadamer enquanto intérprete de Platão e, mais especificamente ainda, constitui um desdobramento do meu texto "Filosofia enquanto Fenomenologia e Hermenêutica à luz da Carta VII de Platão”, in BOMBASSARO, L. C.; DALBOSCO, C. A.; KUIAVA, E. A. (org.). Pensar Sensível. Caxias do Sul, RS: Educs, 2011. pp. 87-104.

5 ARISTÓTELES. Metafísica. Trad. Marcelo Perine. São Paulo: Loyola, 2002. p. 11; I, 982 b20. 
Para levarmos a bom termo nosso propósito nossa reflexão se desenvolverá em torno de dois momentos interconectados entre si: (1) partiremos da exposição de alguns pressupostos hermenêuticos para leitura filosófica do texto platônico (2) a fim de explicitar nossos elogios à verdadeira filosofia.

\section{Contexto hermenêutico para ler, tirar proveitos e responder à Carta Sétima}

Quando alguém escreve uma carta a outrem, ele o faz com vistas a que a leia de modo a dela tirar proveitos propostos ou até pedidos! Ora, uma carta filosófica, como é o caso da Carta Sétima ${ }^{6}$ de Platão, pede nossa resposta na medida em que, tanto sua escritura quanto sua leitura possuem origem e endereçamento universais. Lemos na carta que ela foi dirigida aos amigos e parentes de Dião e nós, como amigos do saber, somos, portanto, também seus destinatários, de modo que ela se torna passível de ser respondida por nós ainda hoje. Dessa maneira, tanto o escritor quanto o leitor encontram-se eivados de uma proposta que extrapola os âmbitos da particularidade uma vez que nela todos se encontram espelhados e podem nela [se] refletir. Diferente de uma epístola filosófica, as demais se assentam - de modo geral - sobre proposições limitadas em termos temporais e espaciais como é caso de uma carta escrita para pedir dinheiro ou comunicar o falecimento de alguém! Dizemos que a primeira é filosófica [leia-se, universal] à medida que não apenas é endereçável a todos, mas também a todos possibilita tirar proveitos e instaurar sentidos de sua leitura na medida em que nos proporciona refletir sobre nossas vidas do ponto de vista pessoal, ético, político e metafísico.

Considerando o pressuposto acima, declaramos que não nos dedicaremos à polêmica discussão sobre a autenticidade da Carta Sétima. Nesse ponto estamos de acordo com Irwin para quem "não podemos esperar chegar a conclusões firmes sobre quem escreveu a Carta", mas

6 Retomo aqui a Cronologia da Carta Sétima: "A Carta VII é escrita mais ou menos depois da morte de Dião, em 354 a.C. Os principais eventos que a antecedem são a primeira viagem de Platão à Itália meridional, Tarento e Siracusa, em 388/387; o governo da Sicília de Dionísio II, sucessor de Dionísio I, morto em 367; a segunda viagem de Platão a Siracusa, 367/366, por insistência de Dião, de onde consegue sair em 361/360, com ajuda de Arquitas; encontro, nesse ano, entre Platão e Dião, nos jogos Olímpicos; em 359, Filipe II, pai de Alexandre Magno, sucede Pérdicas, no governo da Macedônia; em 357, Dião, em uma expedição a Sicília, expulsa Dionísio II; em 354, Dião é morto por Calipo. É neste momento que Platão escreve aos familiares e companheiros de Dião", in PLATÃO. Carta VII. texto estabelecido e anotado por John Burnet. Introdução de Terence H. Irwin. Tradução do grego e notas de José Trindade dos Santos e Juvino Maia Jr. Rio de Janeiro: Ed. PUC-Rio; São Paulo: Loyola, 2008. p. 45. 
plausivelmente poderemos afirmar alguma coisa sobre o autor, se não for Platão. (1) Mostra ter familiaridade com o estilo de Platão. (2) Estava bem informado sobre a história política de Siracusa e o papel que Platão nela desempenhou. (3) Tinha alguma razão para se entregar ao esforço considerável exigido pela escrita desta longa defesa da conduta de Platão. Alguém que possa ter aceite gostosamente o desafio de escrever no estilo de Platão, ou de enganar o público leitor, poderia terse esforçado menos. (4) O seu pensamento filosófico foi formado num ambiente platônico, mas desenvolveu-se numa direção original, ao formular a tese da inexpressabilidade. (5) Queria salvaguardar a reputação de Platão contra os muitos que afirmavam ter publicado descrições escritas da filosofia platônica. (6) Não estava, porém, interessado em Sócrates, como filósofo, ou em defender Platão como herdeiro genuíno de Sócrates, contra os muitos que se apresentavam como herdeiros do manto socrático. (7) Embora se achasse bem informado sobre Platão em Siracusa, não estava bem informado sobre o julgamento e a morte de Sócrates. (8) Queria mostrar que Platão tinha apoiado firmemente Dião e nunca tinha defendido Dionísio contra Dião (apesar das muitas provas em contrário). ${ }^{7}$

Contudo, "o fato de Espeusipo ser um candidato plausível para a autoria da Carta não mostra que de fato o é. Embora as semelhanças políticas e filosóficas sejam sugestivas, nem por isso são conclusivas". ${ }^{8}$ Assumimos a posição de G. Reale sobre esta questão: "a tentativa de negar a autenticidade da Carta VII fracassou, e a grandíssima maioria dos estudiosos admite sua autenticidade". 9 Ao lado dessas duas posições, com as quais nos alinhamos, apresentamos a seguir a nossa compreensão filosófica relativa ao texto em questão.

Partimos do pressuposto segundo o qual, um texto muito bem escrito, como é o caso em questão, uma vez escrito e possibilitando a instauração de sentidos, possui certa autonomia e vida própria, de modo que se torna passível de compreensão e projeção de [novas] realidades a-pesar ou a-favor daquele que a escreveu. Num certo sentido, isso nos dispensa, em parte, da exclusiva obsessão acerca da autenticidade relativa à autoria e localização temporal, embora isso faça parte do processo compreensivo de qualquer texto filosófico. Pensamos que o cuidado com a autenticidade do escrito - o que designamos como tarefa da hermenêutica metodológica ${ }^{10}$ - equipara-se e é tão fundamental quanto são os três primeiros passos do processo dialético proposto pela Carta Sétima. Porém, em complemento a este movimento

7 IRWIN, T. H. "Introdução à Carta VII, de Platão". In: PLATÃO. Carta VII. Rio de Janeiro: Ed. PUC-Rio; São Paulo: Loyola, 2008. p. 40-41.

8 Ibid., p. 43.

9 REALE, G. "A grande importância da Carta VII para o pensamento de Platão". In: PERINE, M. (org.). Estudos Platônicos. São Paulo: Loyola, 2009. p. 223.

10 ROHDEN, L. "Hermenêutica metodológica e hermenêutica filosófica". In: Hermenêutica. Caxias do Sul: UCS, 2008b. pp. 35-57. 
muito importante, o essencial mesmo, é sua leitura hermenêutico-filosófica, o que, à luz da proposta dialética da carta de Platão, equipara-se ao quarto e ao quinto instantes. Temos até a impressão de que a primeira proposta de leitura tem ocupado maior espaço e tempo na academia com o agravante de confundirem-na com filosofia. Nós nos posicionamos ao lado daqueles outros que se ativeram à sua abordagem mais propriamente filosófica e, por isso, nos são suficientes os argumentos relativos à autenticidade de T. Irwin e G. Reale. Eis por que auscultaremos e procuraremos explicitar o que consideramos ser o cerne da carta de Platão, ou seja, sua e nossa proposição de um elogio da verdadeira filosofia em função da qual os personagens e os fatos históricos participam do jogo filosófico como coadjuvantes e não como atores principais.

O parágrafo precedente pode ser escrito e lido ainda de outros modos: ou tomamos um texto como um objeto a ser dissecado segundo o procedimento analítico não restando ao final senão um conjunto de cacos desconexos entre si ou o consideramos como um parceiro no jogo ${ }^{11}$ filosófico. Segundo nossa perspectiva hermenêutica, a epístola dirigida a todos os que amam o saber é tomada como uma realidade com a qual nós jogamos nos jogando nela e ela nos joga de volta ao mundo mais universais, mais unos e mais conscientes da nossa participação na alma do mundo. Ao lê-la, não apenas adquirimos mais informações, mas somos transtornados e instados a sermos melhores, mais justos e verdadeiros.

Sob essa perspectiva, podemos dizer que nós nos lemos na carta filosófica: a. porque ela é constituída pela universalidade temática e tecida pela oralidade escriturística ${ }^{12}$; b. porque ela provoca e pede nossa posição [pessoal e social] pela abrangência de sua emissão e, portanto, recepção ${ }^{13}$; c. por possuirmos certa intimidade com tais coisas, pois alguém dado apenas aos prazeres do corpo não possuirá a sensibilidade filosófica própria das almas para com as coisas que são de muita importância ${ }^{14}$. No jogo de leitura da carta em questão o que importa mesmo é o alargamento da nossa consciência e, consequentemente, de nossa ação [em relação a nós mesmos, aos outros e ao mundo] segundo a lógica de uma coerência universal. Mais importante que pretender assumir o controle do jogo tal como se propõe o jogo totalitário,

11 Sobre a noção de jogo ver ROHDEN, L. "2.1. O jogo como modelo estrutural da experiência hermenêutica”. In: _. Hermenêutica filosófica. São Leopoldo: Ed. Unisinos, 2003. pp. 109-151.

12 "Só a poesia, com efeito, pelos seus caracteres específicos [...] pode ser memorizada, fixada de maneira estável e, portanto, reutilizada. Por conseguinte, o discurso dialético impõe necessariamente o uso da escrita para a sua memorização e reutilização", REALE, G., op. cit., p. 214.

13 Sobre isto ver ISER, Wolfgang. O ato da Leitura. Vol. 1. SP: Editora 34, 1996; O ato da Leitura. Vol. 2. SP: Editora 34, 1999.

14 Sobre isso ver REALE, op. cit., p. 223. 
no jogo hermenêutico - mergulhamos nas entrelinhas da carta - e também emergimos dela mais unos assumindo nossa humanidade pela leitura dialéticotensional entre o jogar-se nela e o jogar com ela. Desse modo, a apropriação de textos filosóficos constitui-se para todos nós, como Gadamer sustenta, uma espécie de encontro conosco mesmos que nos arranca da nossa particularidade e nos projeta na universalidade em crescente sintonia com a alma do mundo. Pensamos que uma questão filosófica é aquela na qual nós estamos sempre de alguma forma autoimplicados e que procuramos resolver e, no caso, pelo caminho da escritura.

Nossa leitura da carta em questão se articula dialeticamente sobre três movimentos compreensíveis conjuntamente em Platão para nossos dias: estilo filosófico, razões para escrevê-la, sobre o processo iniciático filosóficopolítico.

\subsection{Sobre o ponto de vista estilístico}

Do ponto de vista estilístico, estamos diante de um escrito tecido: (a) poruma linguagem, por assim dizer, mais pessoal/subjetiva, uma vez que nela o filósofo emite impressões pessoais e expressa sua opinião sobre sua vida: vou tentar expor-vos do começo tudo o que houve, por parecer-me oportuna semelhante confissão. Quando moço, aconteceu comigo o que se dá com todos [...] [324b-c]; (b) que revela o descompasso entre seu idealismo político e a realidade política de então; (c) que expressa os percalços da prática política e os entraves para se viver de modo virtuoso. Esse tom mais subjetivo e a confissão pessoal sobre questões éticas, políticas, metafísicas é objeto de desconfiança e de dúvida por parte daqueles que se aferram a um conceito universal e vazio de filosofia ou apenas às leituras metodológicas, canônicas. Assumimos aqui nossa preferência por este estilo epistolar de Platão - que, por sua vez, encontra-se em consonância com a proposta hermenêutica desenvolvida por Gadamer - visto que ele nos permite erigir e emitir argumentos filosóficos tecidos com nossas opiniões e juízos sobre o real.

\subsection{Sobre o ponto de vista das razões para Platão viajar e escrever a} carta

O que se disse acima se lê na introdução da Carta Sétima, onde Platão confessa os motivos que o levaram a escrever: escrevestes-me para que eu tenha a certeza de que vossos projetos são iguais aos de Dião, e pedis ajuda de minha parte, na medida do possivel, por atos ou palavras. Eu, de mim, só vos digo que se vossa maneira de pensar e vossos planos forem como os dele, disponho-vos a ajudar-vos [323 d-324 a] e, nessa perspectiva, com tal 
missão, de ajudar pela prática - idas e vindas de Siracusa para instruir o mau tirano ${ }^{15}$ - ele decidiu não apenas falar, mas também escrever sobre seu projeto filosófico, ou seja, sobre a ideia de serem livres os siracusanos e se governarem de acordo com as melhores leis assim como qual tenha sido a origem dessas ideias é o que moços e velhos precisarão saber. Por isso, vou tentar expor-vos do começo tudo o que houve, por parecer-me oportuna semelhante confissão [324 b]. É patente, aqui, o tom pessoal e a declaração dos pressupostos de Platão para redigir a epístola: ele o faz na esperança da efetivação de uma vida mais livre regida por leis justas. Por essa razão, pareceu-lhe oportuna semelhante confissão; sua explicitação fenomenológica visava contribuir, por meio de palavras, para a consecução do seu projeto ético-político, precedido pela práxis, ou seja, pelas tentativas, mesmo que aparentemente frustradas, de tornar Dionísio um bom tirano. O fato é que Platão procurou atender a um pedido de instauração da liberdade e justiça, por meio da exposição escrita de sua prática filosófica, supondo a empatia e a aderência dos amigos e parentes de Dião para com seu projeto político.

Enfim, as razões para aceitar viajar - mesmo que as três viagens tenham sido, aparentemente, fracassadas - assim como as motivações para redigir a carta, estão eivadas com sua experiência de vida, de modo que o texto escrito se converteu numa ajuda oportuna aos mais moços e mais velhos do seu e do nosso tempo.

\subsection{Sobre seu e nosso processo iniciático filosófico-político}

$\mathrm{Na}$ introdução - nos deparamos ainda com outra dimensão importante que tece o escrito epistolar, ou seja, seu idealismo político idealizado-juvenil contrastado e confrontado com a prática política corrupta e distorcida de Atenas que patrocinara a morte do seu mestre. A ingenuidade política e a concomitante confissão de Platão, quanto a este ponto, remete à experiência humana universal: aconteceu comigo o que se dá com todos: firmei o propósito, tão logo me tornasse independente, de ingressar na politica [324 b-c], visto que ela parecia o meio mais apropriado para fazer com que as cidades pudessem passar das vias da injustiça para as da justiça, porém, levando-se em conta a minha mocidade, não é de admirar que eu tivesse ilusões [324 d]. E tamanha

15 Veja-se a pertinente afirmação de Irwin sobre esse termo: "o grego tyranos, habitualmente traduzido por 'tirano', refere-se a um governo monárquico, assegurado e garantido por meios extraconstitucionais, não garantidos pelas leis de uma cidade. Entre os tiranos gregos contam-se Pisístrato, em Atenas, Gelon e Hieron, em Siracusa, que poderiam ser considerados necessários e salutares para suas cidades, nas suas circunstâncias históricas específicas", IRWIN, T. H. "Introdução à Carta VII, de Platão". In: PLATÃO. Carta VII. Rio de Janeiro: Ed. PUC-Rio; São Paulo: Loyola, 2008. p. 7, nota 2. 
foi sua desilusão com a prática política de Atenas que nos confessou sua revolta e intenção de se manter afastado daquelas práticas odientas [325 a].

A questão a se pensar agora é por que sua desilusão se referia a Atenas e não à Siracusa? Talvez porque, nessa última, ele tivesse vislumbrado maiores chances e perspectivas de implantar seu projeto filosófico-político, pois nela havia um tirano com simpatias pela filosofia e havia um amigo seu que incorporara sua proposta política. Em todo o caso, o que é claro, aqui, é sua fenomenologia da realidade humana com relação à política: na idade juvenil somos tomados pelo idealismo e, de modo geral, mais tarde pela desilusão, descrédito e ignorância política. Ele mesmo no-lo revela isso escrevendo: $a$ tal ponto as leis escritas e os costumes se achavam desmoralizados, que eu próprio, a princípio, tão cheio de ardor para dedicar-me à causa pública, considerando a situação reinante e vendo como tudo se achava na mais completa dissolução, acabei tomado de vertigens [325 d-e]. Contudo, em Platão encontramos, em sua idade mais madura, o esforço para efetivar, mesmo com enormes dificuldades, seu projeto filosófico-político. O notável, aqui, é o relato de Platão, em idade avançada, nos revelando a vivência da superação da primeira ingenuidade política e sua insistência na prática como lemos na carta:

todavia, não desanimei de encontrar remédio para esse estado de coisas, sempre à espera de ocasião oportuna para poder agir. Por fim, cheguei à conclusão de que as cidades do nosso tempo são mal governadas, por ser quase incurável sua legislação, a menos que se tomassem medidas enérgicas e as circunstâncias se modificassem para melhor [325 e - 326 a].

$\mathrm{Na}$ carta nos relata a cura de sua primeira ingenuidade relativa ao ideal filosófico-político bem como sua experiência da segunda ingenuidade na qual se sabe quão difícil é a tarefa do exercício político segundo a égide do bem, do justo, do verdadeiro. O comum dos mortais acaba adormecendo nas vertigens da primeira ingenuidade.

A sensibilidade de Platão, sua in-comodação com a situação política de então e seu projeto filosófico-político motivaram-no: a) a viajar e assumir os riscos decorrentes das três viagens à Siracusa; b) escrever sua experiência política com o intuito de contribuir para a efetivação de uma vida mais livre e justa; c) tecer um texto - apontando os inúmeros entraves para o exercício do autêntico filosofar; d) e, por fim, redigir uma carta com o intuito de tecer elogios à sua concepção de verdadeira filosofia, como veremos a seguir. 


\section{Elogios ao elogio da verdadeira filosofia}

Na sequência do supracitado trecho da carta, Platão nos revela o que consideramos ser o motivo central do seu escrito. Ao nos relatar a experiência da sua vivência política, ele, agora por meio de palavras, se dispôs a contribuir para a implantação uma vida mais livre e justa através do elogio à verdadeira filosofia:

dai, ter sido levado a fazer o elogio da verdadeira filosofia, com proclamar que é por meio dela que se pode reconhecer as diferentes formas da justiça politica ou individual. Não cessarão os males para o gênero humano antes de alcançar o poder a raça dos verdadeiros e autênticos filósofos ou de começarem a seriamente filosofar, por algum favor divino, os dirigentes das cidades [326 a-b].

Ora, em nossa opinião, este é o cerne da epístola platônica, porém, compreensível e justificável no conjunto da vivência política de Platão e do seu processo de elaboração conceitual projetetado no texto em questão. É considerando o tom pessoal, humano e prático da carta que convém compreender melhor o que ele se propôs nela, ou seja, tecer e justificar o elogio da verdadeira filosofia.

\subsection{Elogio à vida justa e livre sob a égide da lei.}

Em primeiro lugar, encontramos, na carta, certas pistas relativamente objetivas que justificam as idiossincrasias da autêntica proposta filosófica contida nos elogios da verdadeira filosofia e do bom uso do poder. Mostramos ${ }^{16}$ que não se deve confundir amor ao saber com amor e mau uso ou subserviência ao poder, às riquezas e aos prazeres físicos.

2.1.1. Viver de modo temperante. Estamos de acordo com Platão na perspectiva de que não deveríamos confundir felicidade com seus traços aparentes como lemos na carta:

[...] não me agradou, em absoluto, a vida que por aquelas bandas dão o nome de feliz, passada em festins o dia todo, à maneira itálica ou siciliana, em que a gente se empanturra de comida duas vezes ao dia e só dorme acompanhado [...] Com tais hábitos, não há debaixo do céu quem, com semelhante regime desde moço consiga tornar-se temperante -... - valendo para idêntico raciocinio para as demais virtudes. Nenhuma cidade, também, tenha as leis que tiver, poderá viver tranquila, quando os cidadãos consideram de bom aviso gastar dessa maneira e não ocupar-se com mais nada se não for comer e beber á farta, só pensando nos prazeres do amor [...] sem que os detentores do poder admitam sequer ouvir o nome de um governo de justiça e igualdade [326 b-d] 
É clara a decepção de Platão para com os maus hábitos dos sicilianos. A condição para efetivação da filosofia se faz pela clareza sobre o que é felicidade [pautada pela temperança e exercício da virtude]. A vigência de uma vida filosófica não depende apenas da existência de leis justas, mas de bons hábitos. Estes implicam ainda no não apego e às riquezas, pois, o indivíduo ávido de riquezas, porém de alma tacanha, não escuta esses discursos [335 b]. Ecos dessas advertências encontramos na proposta de Schopenhauer, para quem não se deve confundir o comum profissional do saber [que só procura suas vantagens com seus conhecimentos], com o verdadeiro filósofo, que ama e procura o saber de forma desinteressada no sentido proposto pelo estagirita e que não trata a filosofia como uma moeda de troca ou de barganha.

2.1.2. Melhores leis: patrocínio de vida justa e livre. Além disso, podemos dizer que, na introdução da carta de Platão, encontramos a face objetiva da sua proposta filosófica que o levou não apenas a viajar, mas a escrevê-la: sobre serem livres os siracusanos e se governarem de acordo com as melhores leis [324 b-grifos nossos]. Foi essa motivação objetiva que o levou a fazer o elogio da verdadeira filosofia, pois, por meio, dela é que se pode reconhecer as diferentes formas da justiça política ou individual [326 a].

Por aqui já depreendemos outros dados objetivos implícitos na epístola: que a felicidade encontra-se imbricada como uma prática pessoal e cumprimento da lei e vivência de direitos iguais. É por isso que nos diz, na carta, que a Sicília não deve sujeitar-se a nenhum déspota, nem ela nem qualquer outra cidade-pelo menos, é assim que eu penso-mas às leis [334 c]. Assim, também o tirano deve reger sua vida à luz da lei justa [bom tirano] e não pode se arvorar no direito de se considerar a própria lei [mau tirano].

A queixa de Platão relativa ao assassinato de Dião não se deveu apenas à sua amizade a ele, mas por haverem tirado a vida a um homem que se achava no ponto de realizar a justiça $[335 \mathrm{~b}]$ e por seu ressentimento para com Dionísio o que nos revela outra dimensão relativamente objetiva da sua proposta:

se a filosofia e o poder se tivessem reunido em sua pessoa, ele faria luzir aos olhos dos helenos e dos bárbaros e gravar no espirito dos homens a noção verdadeira de que não podem ser felizes nem as cidades nem os indivíduos, se todos não viverem sabiamente sob o amparo da justiça $[335 \mathrm{~d}]$.

Platão supunha que Dião tivesse a pretensão e pudesse livrar Siracusa da escravidão e fosse capaz de aplicar as melhores e mais convenientes leis segundo pressuposto de que se tudo isso houvesse sido levado a cabo por um homem justo, corajoso, temperante e filósofo, então a maior parte dos homens teria feito da virtude a mesma ideia [336 a-b]. Contudo, segundo Platão, a ignorância dessa proposta pôs tudo a perder. Enfim, a validade 
objetiva relativa está, também atestada na defesa a Dião que, para ele, só ambicionava implantar nova constituição e leis melhores e mais justas, com o menor número possível de execuções ou penas de banimento [351 a]. O fato hermenêutico é que aqui encontramos atestada a conjunção dialética entre vida justa, temperante e livre do ponto de vista pessoal e da polis, ou seja, entre ética e política.

2.1.3. Bom uso do poder. É clara a crítica de Platão ao mau uso do poder realizado por Dionísio, ou seja, seu apego e sua defesa de interesses pessoais escusos. Seu bom uso implicaria no exercício político e não demagógico onde o poder é utilizado para controlar pessoas, obter e garantir vantagens individuais e praticar o nepotismo. À diferença de quem apenas dita, o bom tirano sabe coordenar atividades, projetos sem recorrer à ditadura de regras e normas.

O bom uso do poder implica a vigência da difícil arte de respeitar, ouvir, compreender o outro sem deixar-se determinar por aquela predisposição totalitária, a priori, de tratá-lo como ameaça e, portanto, um perigo a ser combatido ou até eliminado em todos os espaços e tempos. A argumentação aberta é o meio para se justificar o que é o melhor, o mais justo, o mais apropriado.

À diferença da postura de apego obcecado ao poder em defesa de interesses pessoais de Dionísio, Platão nos propõe seu exercício em função da coisa pública. O filósofo, além de saber lidar bem com o poder possui a capacidade de utilizá-lo para dirigir a cidade sob a égide da justiça e da liberdade. A busca do controle do poder para dominar, obter e garantir vantagens individuais de alguém que se diz filósofo implode qualquer discurso ético seu. O filósofo não possui uma alma tacanha [335 b], servil ou dissimulada, mas possui a coragem para debater e discutir questões que são, de fato, pertinentes ao bem público. A liberdade no trato com os outros se arraiga na [sua] busca da verdade e do que é o melhor e por isso não depende da bajulação dos mais fracos para garantir o uso do poder.

\subsection{Elogios à vida sábia!}

Um pressuposto fundamental da verdadeira filosofia, em Platão, é a distinção entre filósofo sábio e filósofo aparente, entre aquele que se esforça para conhecer e viver a verdade, a unidade, a beleza e aquele que se atém apenas ao estilo persuasivo, pomposo e petulante de seus discursos. ${ }^{17} \mathrm{Nesse}$ sentido, inteligência, esperteza, sagacidade não podem, a priori, serem 
considerados sinônimos de sabedoria embora possam ser atributos do filósofo sábio. A sabedoria filosófica implica não apenas o domínio e o acúmulo de conhecimento, de informações, mas também a vivência do bem e da verdade; o filósofo aparente até entende o real, mas o sábio é aquele que o 'compreende' ${ }^{18}$ Vejamos três implicações decorrentes dessa proposição.

2.2.1. Aqueles que se atêm apenas à aquisição de informações filosóficas e se aferram ao que julgam conhecer se assemelham aos que não são verdadeiros filósofos e só receberam um verniz de opiniões superficiais, à maneira dos corpos queimados pelo sol [340 d-e]. Assim como uma andorinha só não faz verão não basta um dia ou um mês ou a aquisição de certos conceitos ou de um diploma para alguém ser considerado filósofo, mas precisa passar pelas provas propostas por Platão na carta [340 b - 345 c]. O filósofo que aspira à sabedoria [a viver de modo sábio] possui uma postura que não se coaduna com a arrogância nem com o dogmatismo. Paradoxalmente, quem mais se aproxima da raiz do real, mais incorpora a simplicidade de vida dos grandes sábios, o que não significa subserviência ou passividade!

Além disso, o filósofo reluta em escrever seja por sua incompetência e finitude, seja pela limitação própria da linguagem, seja pela inesgotabilidade do fim último do filosofar. Daí a discussão sobre a primazia da linguagem oral, dialógica em relação à escrita. Diferente de Dionísio, Platão sabia do perigo a que se expunha ao escrever 'sobre o bem', pois não é possível encontrar a expressão adequada para os problemas dessa natureza, como acontece com outros conhecimentos [341 c]. Como se vê, o cuidado do filósofo em relação à escritura filosófica não se deve à sua preguiça, mas à sua consciência da in-competência e incessante busca por encontrar a palavra apropriada aos contornos das coisas. O filósofo ousa criar, segue suas intuições a partir da competente apreensão da história da filosofia, sem esquecer, contudo, que não possui a última palavra afinal "a essência do comportamento hermenêutico caracteriza-se em não se guardar nunca, para si, a última palavra", ${ }^{19}$ [sobre si, sobre os outros, sobre o real].

18 De acordo com Gadamer "a palavra 'compreender' (verstehen) também pode nos auxiliar aqui [...] Compreender (verstehen) designa em alemão o ato de 'representar alguém' (für jemanden stehen). Segundo o seu sentido originário, a palavra refere-se àquele que se mostra como representante no tribunal, o advogado. Ele é aquele que 'compreende' o seu partido, ou tal como dizemos para tanto no uso linguístico de hoje, alguém que o 'represente'. Ele representa o seu cliente, ele se coloca em seu lugar: ele não repete, por exemplo, aquilo que seu cliente lhe expõe ou dita, mas ele fala por ele", in "Romantismo primevo, hermenêutica e descontrutivismo (1987)" que está em GADAMER, H.G. Hermenêutica em retrospectiva, vol. II. Rio de Janeiro: Vozes, 2007, pp. 70-71.

19 GADAMER, Hans-Georg. "Retrospectiva dialógica à obra reunida e sua história da efetuação" - Entrevista de Jean Grondin com Hans-Georg Gadamer. In: ALMEIDA, C. L Silva de; FLICKINGER, H-G; ROHDEN, L. (org.). Hermenêutica filosófica; nas trilhas de Hans-Georg Gadamer. Porto Alegre: Edipucrs, 2000. p. 211. 
2.2.2. O filósofo vive a verdade, a bondade, a unidade nas mínimas coisas. Filosofia não é apenas uma questão de conhecimento, mas de postura, de prática e implica uma opção de viver de modo autônomo e responsável como lemos na carta: é nesse estado de espírito que tal homem vive; e até mesmo nas ocupações mais triviais, a todo instante e em quaisquer circunstâncias não se despega da filosofia [340 d-grifos nossos]. O filósofo sábio não chega em casa e tira seu jaleco para viver um personagem diferente daquele que sua profissão the exige.

2.2.3. É relativamente aceitável que sejam considerados filósofos ainda hoje pessoas despreocupadas em conhecer-se e cuidar-se de si mesmas. A esquizofrenia entre estas duas polaridades - ou a identificação da filosofia à apenas um dos polos - tem produzido verdadeiras aberrações acadêmicas e tendências totalitárias combatidas desde os tempos de Platão como lemos na carta.

Contudo, corroboramos a opinião de Platão, segundo a qual, a filosofia se erige sobre a imbricação dialética entre o processo de [auto]conhecimento e o ser, isto é, o esforço de cuidar-se de si mesmo e de [re]-elaborar conceitos. Dito de outro modo, na vida sábia o filósofo e a filosofia, o sujeito e o objeto, o particular e o universal encontram-se e espelham-se o que, nas palavras do prof. Porchat foi expresso assim: "ensinar a filosofar exige que se filosofe também". ${ }^{20}$ Sabemos que o filósofo sábio não é insensível, mas aberto e capaz de ouvir e argumentar com o outro. Além disso, ele ousa inclusive olhar para sua própria casa ou para os seus entraves ao emitir juízos acerca do real. Enfim, de acordo com a proposta de Platão e nossa, filosofar significa aprender a viver conforme o que nos torna mais divinos e, portanto, mais humanos.

2.3. Elogio à escritura na alma enquanto uma vida digna de ser vivida

2.3.1. Experiência filosófica = escritura na alma! Ao lado da reflexão anterior, compreendemos que a efetivação do filosofar acontece enquanto uma experiência de vida digna de ser vivida ou o que equivale a uma mensagem escrita na alma! Nas entrelinhas da carta de Platão é possível perceber que sua afirmação: de mim, pelo menos, nunca houve nem haverá nenhum escrito sobre semelhante matéria [341 c], precisa ser compreendida com o que diz na frase a seguir: não é possível encontrar a expressão adequada para problemas dessa natureza, como acontece com outros conhecimentos [341 c]. Transparece, aqui, a posição platônica - com a qual estamos totalmente de da USP, 18 de maio de 1998, p. 9. 
acordo - segundo a qual nem a escritura nem a oralidade são capazes de conter a largura e a profundidade da filosofia. Esta possui uma expressão própria, distinta de conhecimentos em geral. Quando dizemos que o real e, portanto, a filosofia, não se deixa engessar ou açambarcar por conceitos não é porque ela é inexpressável, mas porque não se expressa nem se esgota em palavras como outros conhecimentos. Conhecemos o significado da palavra carro com relativa rapidez, porém, o termo filosofia implica uma compreensão distinta, gradual e inesgotável. Enquanto que o primeiro tipo de conhecimento restringe-se ao tipo de informação padronizada, a filosofia instaura-se como consequência de um comércio prolongado e de uma existência dedicada à meditação de tais problemas é que a verdade brota na alma como a luz nascida de uma faísca instantânea, para depois crescer sozinha [341 c-d; grifos nossos]. Ela constitui uma experiência [hermenêutica] que se efetiva, dialogicamente, em colóquios amistosos sem ressaibos de inveja, onde perguntas e respostas visam à compreensão conjunta mais universal do real. Ora, esta busca tensional é o que caracteriza o sábio ao passo que o profissional do saber, normalmente, está às voltas com uma espécie de universalidade desvencilhada da ontologia. Essa experiência inscreve-se nas almas e parece pedir dispensa da sua escrita nos rolos de papel [ao modo de filosofar de Sócrates], pois, o que sabemos por experiência, não esquecemos nem precisa ser, necessariamente, impresso em textos. Porém, se o fazemos ${ }^{21}$, é apenas para nos compreendermos mais e melhor e, quem sabe, para que outros possam disso tirar algum proveito, como alegou Platão.

O filosofar, para além do uso de proposições lógicas, do domínio de conhecimentos e conceitos, da habilidade no uso das palavras, ele se caracteriza como um exercício [re]-criador de [novas] realidades, afinal, o tempo está a nos enterrar o tempo todo! Diante disso, ao filosofar, instauramos novas possibilidades de viver calcadas na leitura da tradição e das nossas projeções. Desse modo, filosofar significa aspirar à sabedoria, à busca de clareza na travessia ${ }^{22}$ mesma do real, levando em conta o passado, o futuro, no presente, sem se aferrar a uma das faces do tempo. Sábio e não mercenário, aquele mostra sua filosofia por sua postura, pelo cuidado com o uso das palavras em sua fala e em sua escrita. A experiência filosófica não culmina, pois, no silêncio ou no mutismo, mas na vivência e concomitante consciência da

21 ROHDEN, L. "Sobre a Arte de escrever filosofia filosoficamente". In: KUIAVA, E. A.; SANGALLI, I. J.; CARBONARA, V.; Filosofia, Formação docente e Cidadania. 1. ed. Ijuí: Unijuí, 2008a. p. 215-234. (v.1).

22 "Digo: o real não está na saída nem na chegada: êle se dispõe para a gente é no meio da travessia", ROSA, J. G. Grande Sertão: Veredas. 2. ed. Rio de Janeiro: José Olympio Editora, 1958. pp. 62-63. 
limitação de todo esforço conceitual relativo à nossa hermenêutica do real. Se a filosofia é uma postura, um modo de vida como nos propõe a leitura de Hadot $^{23}$ sobre Platão, com o qual concordamos, ela é também um esforço incessante de caminharmos das palavras ao conceito e destes àquelas ${ }^{24}$ o que tece nossa concepção do filosofar enquanto uma experiência.

2.3.2. Experiência da escritura filosófica. Com relação ao tema da escritura filosófica, parece que os profissionais do saber creem, normalmente, ou na expressabilidade total da filosofia via conceito [formalização] e consequente dogmatismo ou na sua inexpressabilidade e consequente mergulho numa espécie de abismo silencioso. Porém, o filósofo, enquanto um iniciado à sabedoria, tem consciência seja da inesgotabilidade da filosofia, seja da sua concomitante limitada expressabilidade. Daí que a re-leitura da carta em questão, corrobora o fato de que o conceito de filosofia constitui-se em um exercício, uma troca, um comércio prolongado e de uma existência dedicada à meditação [341 c] configurando a experiência filosófica onde objetividade e subjetividade encontram-se articuladas conjunta e dialeticamente. Desse modo, o saber próprio do sábio não se limita à aquisição e repetição autômata de conceitos. Por exemplo, uma coisa é falar sobre a finitude, o amor, os limites, a morte, outra coisa é senti-los, vivê-los, padecê-los e outra coisa é próprio dos sábios - ser capaz de senti-los, percebê-los e ainda escrever sobre eles apropriadamente. A crítica de Platão a Dionísio deveu-se, em parte, à sua pretensão de escrever e repetir fórmulas filosóficas sem haver se esforçado por vivê-las e por isso sua escritura era estéril.

2.3.3. Experiência filosófica de uma vida digna de ser vivida. Com o elogio da verdadeira filosofia - enquanto realização de uma experiência de verdade, de beleza e de bondade - quem tiver vocação para tal empreendimento, ou seja, se se tratar, realmente, de um amante da sabedoria e se for dotado de natureza divina, além de revelar vocação para tais estudos, ficará maravilhado com o caminho apontado e no mesmo instante se decidirá a enveredar por ele e a não viver de outra maneira [340 c, grifos nossos]. Ora, de modo mais contundente ainda, de acordo com Platão, nas palavras de Sócrates "uma vida sem pensar não é digna de ser vivida por um homem". ${ }^{25}$ Essa vida digna de ser vivida é aquela que nos convoca a uma constante compreensão mais verdadeira e universal de nós mesmos e do mundo. Sábios e, portanto, felizes

23 HADOT, P. O que é a filosofia antiga? São Paulo: Loyola, 1999 e HADOT, P. Ejercicios espirituales y filosofia antigua. Madrid: Ediciones Siruela, 2006.

24 GADAMER, H.G. "A incapacidade para o diálogo". In: 2002. pp. 242-252.

25 PLATÂO. Apologia de Sócrates. Lisboa: Imprensa Nacional - Casa da Moeda, 1983, p. 95, 35 a. 
serão aqueles que puderem captar, assimilar e viver isso independente do preço a pagar por isso! Enfim, a questão que colocamos agora é: como se efetiva ou como se deve proceder ou qual o caminho que precisa trilhar aquele que quer ser um filósofo-sábio?! Segundo nossa hipótese investigativa, é pela postura e pelo procedimento dialético-dialógico o que será desenvolvido mais adiante.

\section{Ao modo de uma conclusão}

Como lemos na carta, por palavras e por atos, Platão nos mostra que sua concepção de filosofia se sustenta sobre a imbricação dialética entre um modo de viver - pautado pela noção de unidade, verdade, beleza - e uma proposta teórica, entre uma leitura e concomitante reflexão sobre a realidade [pessoal e política]. A recusa, portanto, em escrever sobre os assuntos mais importantes não se deve ao argumento de que isso seria tarefa exclusiva de um grupo secreto de iniciados nem à sua inexpressabilidade, mas porque o filosofar se erige, justamente, sobre a instauração incessante de uma escritura apropriada e dinâmica aos tempos e espaços de quem se dispõe a tal empreendimento. Assim, de acordo com Platão, o problema daqueles que pretendem fixar a filosofia no texto se deve ao fato de que participam do grupo de gente de tanto valor que nem a si mesmo se conhece $[341 \mathrm{~b}] .{ }^{26}$ Enfim, o encontro com essa belíssima carta nos provoca e nos convoca continuamente a filosofarmos $\mathrm{em}$ colóquios amistosos em que perguntas e respostas se formulam sem o menor ressaibo de inveja de modo que então brilhe, entre e sobre nós, sobre cada objeto a sabedoria e o entendimento de modo que torne nossa vida ainda mais digna de ser vivida.

\section{Referências bibliográficas}

ARISTÓTELES. Metafísica. Trad. Marcelo Perine. São Paulo: Loyola, 2002. GADAMER, Hans-Georg. "Retrospectiva dialógica à obra reunida e sua história da efetuação" - Entrevista de Jean Grondin com Hans-Georg Gadamer. In: ALMEIDA, C. L Silva de; FLICKINGER, H-G.; ROHDEN, L. (org.). Hermenêutica filosófica; nas trilhas de Hans-Georg Gadamer. Porto Alegre: Edipucrs, 2000. pp. 203-222.

. "La filosofia griega y el pensamiento moderno". In: . El início de la sabiduría. Barcelona: Paidós, 2001. pp. 125-132.

. Verdade e Método II. Rio de Janeiro: Vozes, 2002.

26 Isto nos remete ao tema da nossa próxima reflexão em torno da concepção platônica e hermenêutica que se erige sobre a articulação dialética entre cuidado e conhecimento de si enquanto um constante exercício espiritual o que nos ocupará mais adiante. 
. Hermenêtica em retrospectiva, vol. II. Rio de Janeiro: Vozes, 2007.

GUTHRIE, W. F. C. Historia de la Filosofía Griega. Vol. I. Madrid: Editorial Gredos, 1984.

HADOT, P. O que é a filosofia antiga? São Paulo: Loyola, 1999.

. Ejercicios espirituales y filosofia antigua. Madrid: Ediciones Siruela, 2006.

HERÁCLITO. Fragmentos. Rio de Janeiro: Edições de Tempo Brasileiro, 1980.

ISER, W. O ato da Leitura. Uma teoria do efeito estético, vol. 1. São Paulo: Editora 34, 1996.

. O ato da Leitura. Uma teoria do efeito estético, vol. 2. São Paulo: Editora 34, 1999.

PLATÃO. Fedro - Cartas - O primeiro Alcibíades. Trad. Carlos Alberto Nunes. Pará: Universidade Federal do Pará, 1975. (A Carta Sétima encontra-se nas pp. 137-167).

- Apologia de Sócrates. Tradução, introdução e notas de José Trindade dos Santos. Lisboa : Imprensa nacional - Casa da Moeda, 1983.

. Carta VII. texto estabelecido e anotado por John Burnet. Introdução de Terence H. Irwin. Tradução do grego e notas de José Trindade dos Santos e Juvino Maia Jr. Rio de Janeiro: Ed. PUC-Rio; São Paulo: Loyola, 2008.

PORCHAT, Oswaldo. "Discurso aos Estudantes sobre a Pesquisa em Filosofia" Departamento de Filosofia da USP, 18 de maio de 1998, p. 1-10. [Texto publicado em Dissenso - Revista de Estudantes de Filosofia. São Paulo: C. A. Cruz Costa, DFFFLCH-USP, no 2, $1^{\circ}$ sem. (1999), pp. 131-40].

REALE, Giovanni. "A grande importância da Carta SÉTIMA para o pensamento de Platão". In: PERINE, Marcelo (org.). Estudos Platônicos. Sobre o ser e o aparecer, o belo e o bem. São Paulo: Loyola, 2009. p. 211-224.

ROHDEN, L. Hermenêutica filosófica. São Leopoldo: Ed. Unisinos, 2003.

"Sobre a Arte de escrever filosofia filosoficamente". In: KUIAVA, E. A.; SANGALLI, I. J.; CARBONARA, V.; Filosofia, Formação docente e Cidadania.1. ed. Ijuí: Unijuí, 2008a. p. 215-234. (v.1).

. Interfaces da Hermenêutica. Caxias do Sul: UCS, $2008 b$.

"Filosofia enquanto Fenomenologia e Hermenêutica à luz da Carta VII de

Platão". In: BOMBASSARO, L. C.; DALBOSCO, C. A.; KUIAVA, E. A., (org.). Pensar Sensivel- Festscrift ao prof. Jayme Paviani. Caxias do Sul, RS: Educs, 2011. pp. 87-104.

ROSA, J. G. Grande Sertão: Veredas. 2. ed. Rio de Janeiro: José Olympio Editora, 1958. 